\title{
Incorporating Peace Education into Aqidah Akhlak Subject in East Aceh
}

Suadi and Saifuddin

Department of Sociology, Universitas Malikussaleh Aceh, Indonesia

\author{
Fadli \\ Department of Agribusiness, Universitas Malikussaleh, Aceh, Indonesia
}

\begin{abstract}
Purpose - This paper aims to explain the concept of post-conflict peace education that has been implemented in East Aceh.
\end{abstract}

Design/Methodology/Approach - This research used the qualitative method where data were gathered by deep interview and study of documents.

Findings - The results show that the Aceh government education agency has not yet developed a standarized concept of peace education to be implemented throught out the schools in East Aceh. However, non-governmental agencies both national and international have stepped ahead and implemented it in formal and non-formal educational institutions. UNICEF and AusAID had facilitated the preparation of a peace education textbook which was written by academicians at UIN Ar-Raniry in 2005. It has been applied to many schools in East Aceh by incorporating peace education in to Aqidah Akhlak subject.

Research Limitations/Implications - The paper does not examine students' understanding of peace education that can be learnt by incorporating concepts of peace education.

Practical Implications - The concept of peace education is feasible to be adopted at whole senior high school in Aceh.

Originality/Value - This paper offers a new concept of peace education, the liberal peace, religious peace, and traditional values that have been integrated in one subject to be taught at once.

Keywords Aceh, peace education, Post-conflict

All papers within this proceedings volume have been peer reviewed by the scientific committee of the Malikussaleh International Conference on Multidisciplinary Studies (MICoMS 2017).

We are particularly grateful to the Ministry of Research, Technology, and Higher Education of Indonesia for funding this research, and thanks also to the Research and Services Institute of Malikussaleh University for supporting the research. Lastly, we thank all informants in East Aceh for giving us useful information which are used as data in the research.

(C) Saudi, Saifuddin, Fadli. Published in the Emerald Reach Proceedings Series. Published by Emerald Publishing Limited. This article is published under the Creative Commons Attribution (CC BY 4.0) licence. Anyone may reproduce, distribute, translate and create derivative works of this article (for both commercial and non-commercial purposes), subject to full attribution to the original publication and authors. The full terms of this licence may be seen at http://creativecommons.org/licences/by/4.0/ legalcode

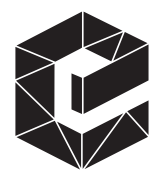

Emerald Reach Proceedings Series Vol. 1
pp. $467-472$ Emerald Publishing Limited DOI 10.1108/978-1-78756-793-1-00013 


\section{Proceedings of 1 . Introduction}

MICoMS 2017

The development of education system in Aceh cannot be separated from the development of the territory and Acehnese political authority from time to time due to prolonged colonialist aggression and conflict in Aceh. This means that educational development in Aceh ties hand in hand with the development of its political identity from one of the Greatest Islamic Empire in Southeast Asia into a province in Republic Indonesia Unitary. The day 15 August 2005 marked the end of numerous wars against colonialists including the Netherlands and Japan, including inter-nation conflict with the Unitary State of the Republic of Indonesia. This situation has deep influence in the implementation of education in Aceh.

Negative impacts arising from prolonged conflict not only hurt physically but also causes greater impact socially with educators, students, and their parents. The number of students were directly involved and impacted by the conflict, especially the senior high school students. Such friction triggered negative attitude on students toward their own educational process. This phenomenon affirms that the Aceh war (1976-2005) has had a negative impact on educational institutions in Aceh (Yunus, 2011).

Studies on the impact of the war on education have also been undertaken by Akresh (2008) Bellows and Miguel (2009), Bundervoet et al. (2009); Dube and Vargas (2006), Ichino and Winter-Ebmer (2004); Merrouche (2006), and Stewart (2001). The results showed that wars effected education in many ways. First, it reduced the financial resources available to households which would hurt the quality and quantity of the education. Second, students coming from the damaged schools were forced to transfer to other schools, which may also interfere with their education. Third, the precarious situation during the conflict hampered people from leaving home to schools or government agencies fear of the armed forces and militia. Combatants also often target educational institutions for burning, abduction, and intimidation. Fourth, children dropping out of school due to the death of their parents.

Similarly, Acehnese' fighting against the colonialist and the prolonged inter-nation conflict of Aceh was partly contributed by its education system implemented in Aceh. Therefore, conflict, peace, and education have mutual relationships. As also stated by Danesh (2006), peace is a requirement for effective peace education, and peace education will create a higher state of peace.

Furthermore, in article 19 Aceh Qanun Number 11 of 2014 on the Implementation of Education, it was explained that the Government of Aceh has the authority to implement the national curriculum at elementary and secondary education levels. In addition, the Aceh Government also has the authority to develop an Islamic curriculum of Aceh for primary and secondary educations. Then in Qanun Number 9 of 2015 on Educational Enhancement in article 13 point $b$ mentioned that the Government of Aceh guarantees the implementation of quality, equitable, fair, and Islamic education. This description illustrates that the privileges of education in Aceh can be actualized through local content material adapted to the development of the Islamic Shari'a application space in Aceh. Based on the above description, in this study will see the concept of after-conflict peace education with Islam nuanced to schools in East Aceh. To this end, this paper focuses on integrating peace education into the subjects of religious education. This study found that peace education has been taught to students by integrating it into the Aqidah Akhlah lesson which is a part of the national lesson structure.

\section{Methods}

This research used the qualitative approach. It was conducted in Aceh Timur District, Aceh Province, Indonesia. The informants in this study were East Aceh District Education Officer, school supervisors, principals of schools, teachers who taught peace education, and 
students at senior high school level. Data were collected through: (1) in-depth interviews, with asking specific questions to the informants and (2) study of documents, with documenting the bulletins, annual reports, journals, magazines, photographs, and notes/ archives. In addition, all the documents were studied to get suitable information which were used as data for this research.

Data were analyzed through three stages, namely: first, data reduction. It is the process of selecting and simplifying the crude data that emerged from field notes. Second, presentation of data. It is the presentation of a collection of information in the form of narrative text that is assisted with metrics and tables. Third, the conclusion. It is the search for meaning, patterns, explanations, causal paths, and propositions. Data were then performed carefully and systematically by means of verification, rechecking field notes. Thus, the data obtained can be tested by its validity (Neuman, 2002).

\section{Results and discussion}

Although the Helsinki MoU does not mention explicitly "education," post-conflict peace education in Aceh has certainly positive and significant role in preserving the peace agreement in Aceh. Section 1.1 of the Law on Governmental Implementation in Aceh, in letter (a) stated that Aceh will exercise authority in all public sectors, which will be held in conjunction with the civil and judicial administrations, except in the field of external relations, external defense, national security, monetary and fiscal matters, judicial power, and religious freedom. Furthermore, in Section 1.4 the Legislation of Regulations, in the letter (b) the Aceh Legislature shall refer to the legal provisions for Aceh based on the universal principles of human rights as contained in the International Covenant on Civil and Political Rights and on Economic, Social, and Cultural Rights.

Referring to the International Covenant on economic, social, and cultural rights, it is certain that the Helsinki MoU has covered the aspect of education to be undertaken by the Government of Aceh. In Article 13 (1), it is stated that the countries taking part in the covenant recognize the right of everyone to education. Education should be directed to the development of a complete human personality and awareness of his self-worth, and strengthen respect for fundamental human rights and fundamental freedoms. Education should enable everyone to participate effectively in a free society, promote understanding, tolerance, and friendship among all nations and all groups, races, ethnicities, or religions, and further advance the activities of the United Nations to maintain peace.

In an effort to harmonize with the covenant, the Aceh Government has laid the foundation for education in Aceh as described in the UUPA and Aceh Qanun on the Implementation of Education as described above by enhancing the distinctive features of Acehnese Islamic education. However, the LoGA and Aceh Qanun do not explain their educational objectives to build a sustainable positive peace or promote a culture of peace in Aceh as expected by peace experts. Bajaj and Chiu (2009), Reardon (1988), and Spruyt et al. (2014) explain that peaceful education encompasses policy, planning, pedagogics, and educational practices that can raise awareness and develop skills and values of peace. Thus, peace education becomes a medium for building a more tolerant world based on mutual respect, nonviolence, justice, and sustainability (Harris and Morrison, 2012). According to Navarro-Castro and Nario-Galace (2008), peace education is to cultivate knowledge, skills, attitudes, and values to transform thought patterns, attitudes, and behaviors that generate violent conflict. This can be done by building awareness and understanding, developing awareness, and challenging personal and social actions that will enable people to live, connect, and create conditions and systems that can actualize nonviolence, justice, environmental care, and other peace values. 
Proceedings of MICoMS 2017

\section{0}

During the post-conflict period, many peace-building processes have been implemented, but education is not taken into account. UNDP and other agencies have addressed the need for conflict-sensitive programs in all institutions, but have no focus on education and its potential role. In line with this subject, UNICEF has supported the development of a pilot project on education course for high school students based on local cultural and religious values, aimed at promoting nonviolence, and peaceful resolution of conflict among youth and creating awareness about children's rights. Many of these similar programs were not followed by the Aceh Government due to lack of funds, and the Government failed to integrate them into the holistic curriculum reform process (UNICEF, 2014).

Taking all these into account, some international and national NGOs concerned with peace education have implemented peace education in Aceh, both through non-formal educational institutions and formal educational institutions (schools). For example, UNICEF-AusAID has facilitated the compilation of a textbook of peace education conducted by UIN Ar-Raniry academics in 2005 under the title "Curriculum of Aqidah Akhlak in the Context of Peace Education." The textbook was applied to schools in East Aceh at the beginning of Aceh's peace.

However, the Aceh Government through its related agencies has not yet developed a standardized concept of peace education that schools should undertake throughout Aceh. This was evident as stated by some of the informants interviewed for the purpose of this research. Some of them, sadly, do not understand about peace education. Some school teachers, dejectedly, perceived peace education as a peace agreement. A teacher in SMA I Idi Rayeuk, for example, questioned the researcher "what is peace education, I just heard it now." Another informant from the East Aceh Education Office stated "Aceh is now peaceful, so peace education is less relevant in schools. Especially because in East Aceh there has never been a brawl between students"(Interview with Saiful High School Curriculum Section, East Aceh Education Office, 6 July 2017).

The results of observations conducted in three high schools (SMA) namely SMA 1 RantauSelamat, SMK FajarHarapan, and SMK Agriculture Peureulak East Aceh found that the interaction of students in both ethnic and inter-ethnic schools currently in harmony or without conflict (Observation, 28 July 2017). These positive and harmony interactions were because of peace condition in Aceh. Saifuddin (2015) concludes that peace is the main factor in establishing positive interaction between students and students, teachers and teachers, and with students' parents. Therefore, the process of teaching and learning can be done optimally.

Associated with curriculum applied in schools in East Aceh today is referring to Education Unit Level Curriculum and Curriculum 2013 as implemented in schools throughout Indonesia. This is as revealed by the following informants:

Despite having the privileges in education, the Aceh government does not have its own curriculum reflecting the uniqueness of Aceh from all aspects, except for Acehnese language that is taught through the local content subject. Aceh's curriculum has been discussed by the Government of Aceh. The process started in 2014 but then was disconnected/delayed in 2015 due to budget constraint. In 2016 it is being reorganized and in October 2017 it is targeted that the curriculum can be completed and will be disseminated in November. So that in 2018 it can be implemented in several schools as a pilot project. The curriculum is called the Aceh curriculum which encompasses Islamic education, peace education, and local wisdom of Aceh (interview with Ilham and Fakhri, Curriculum Section of Aceh Education Office, 23 August 2017 in Banda Aceh).

Aceh Education Office expects the school to integrate peace education into the school curriculum later on. This can be understood through an exposure of media news about the trip 
to Aceh by 34 teachers from various levels ranging from kindergarten, elementary to junior high school from Patani, Southern Thailand, on 15-17 November 2014. Their visit aims to learn about how the values of Islam, the Aceh culture, and the values of peace are integrated into the school curriculum. According to Head of Disdik Curriculum of Aceh Zulbahri, SPd MEd, the national curriculum is grouped into two sections, namely group A and group B. Group A includes a number of national compulsory subjects such as religious education, Pancasila education, Bahasa Indonesia, Mathematics, Science, and Social Studies. While in group $\mathrm{B}$, given authority to the region to determine the subjects such as peace education, disaster, Islamic education, Islamic history, local excellence, and history (ACSTF, 2014).

The teachers of peace education were trained by UNICEF-AusAID. The concept of peace education conducted in senior high schools in East Aceh refers to the concept of peace education developed by UNESCO combined with the concept of Islamic peace education and the local wisdom of Aceh. Thus, the concept of peace education in Aceh encompasses the concept of universal peace education developed by UNESCO and UNICEF, the concept of peaceful Islamic education, and the concept of peaceful Acehnese cultural education. These all are integrated into a peaceful education curriculum in Aceh, named Aqidah Akhlak, in peace education perspective.

\section{Conclusion}

The Government of Aceh via its agencies has not developed a specific and clear concept of peace education to be implemented at all schools throughout Aceh. Nevertheless, the Aceh Government is currently drafting a concept of "Aceh Education" to be implemented in 2018. The curriculum is called the Kurikulum Aceh which includes Islamic education, peace education, and local Acehnese wisdom. The curriculum will integrate peace education into the school curriculum.

However, the concept of peace education implemented at senior high schools in East Aceh refers to the concept of peace education developed by UNESCO, which combined the concept of peace education, Islamic education, and Acehnese' local wisdom. This process was initiated by UNICEF-AusAID collaborating with academicians from UIN Ar-Raniry. UNICEF has supported the development of a pilot education course for high school students based on local cultural and religious values, aimed at promoting peaceful non-violent and conflict resolution resolutions. Their cooperation has resulted in a Peace Education Textbook in 2005, entitled Aqidah Akhlak Curriculum in the Context of Peace Education. It has been applied to several senior high schools in East Aceh at the beginning of Aceh peace agreement. Therefore, it is expected that the Government of Aceh adopt the curriculum as part of the curriculum structure of education in Aceh, so that the concept of peace education can be taught by religious teachers in all senior high schools in Aceh.

\section{References}

ACSTF. (2014). 34 Guru Patani Belajar Pola Pendidikan Aceh, ACSTF, Banda Aceh. Available: http:// www.acstf.org/2014/11/34-guru-patani-belajar-pola-pendidikan-aceh.

Akresh, R. (2008). Armed Conflict and Schooling: Evidence from the 1994 Rwandan Genocide (Vol. 3516), World Bank Publications, Washington, D.C.

Bajaj, M. and Chiu, B. (2009). "Education for sustainable development as peace education". Peace \& Change, Vol. 34, No. 4, pp. 441-455.

Bellows, J. and Miguel, E. (2009). "War and Local Collective Action in Sierra Leone". Journal of Public Economics, Vol. 93, No. 11, pp. 1144-1157. 
Proceedings of Bundervoet, T., Verwimp, P. and Akresh, R. (2009). "Health and Civil War in Rural Burundi”. Journal of MICoMS 2017

Danesh, H.B. (2006). "Towards an Integrative Theory of Peace Education”. Journal of Peace Education, Vol. 3, No. 1, pp. 55-78.

Dube, O. and Vargas, J.F. (2006). Are All Resources Cursed? Coffee, Oil and Armed Conflict in Columbia, Center for International Development at Harvard University, Cambridge.

Harris, I. M. and Morrison, M.L. (2012). Peace education, McFarland, North Carolina.

Ichino, A. and Winter-Ebmer, R. (2004). "The Long-Run Educational Cost of World War II". Journal of Labor Economics, Vol. 22, No. 1, pp. 57-87.

Merrouche, O. (2006). The Human Capital Cost of Landmine Contamination in Cambodia. Working Papers 25, Households in Conflict Network, Brighton.

Navarro-Castro, L. and Nario-Galace, J. (2008). Peace Education: A Pathways to a Culture of Peace: Centre of Peace Education, Miriam College.

Neuman, W. L. (2002). Social Research Methods: Quantitative and Qualitative Approaches. Boston, MA: Allyn \& Bacon.

Reardon, B. A. (1988). Comprehensive peace education: Educating for global responsibility. New York, NY: Teachers College Press.

Saifuddin, S. (2015). Interaksi Guru dengan Orang Tua Siswa Era Perang dan Damai di Aceh. ISLAMICA: Jurnal Studi Keislaman, Vol. 9, No.2, pp. 402-423.

Spruyt, B. E., Mark, R. L. and Van, D. F. (2014). Can Peace Be Taught? https://www.flemishpeaceinstitute. eu/sites/vlaamsvredesinstituut.eu/files/files/reports/can_peace_be_taught_revised.pdf

Stewart, F., Huang, C., and Wang M. (2001). "Internal Wars: An Empirical Overview of the Economic and Social Consequences". In F. Stewart and V. FitzGerald (eds), War and Underdevelopment, vol. 2. QEH Series in Development Studies. Oxford: Oxford University Press.

UNICEF. (2014). Peacebuilding, Education and Advocacy: East Asia and Pacific Desk Review and Situation Analysis,UNICEF East Asia and Pacific Regional Office, Thailand.

Yunus, S.M. (2011). "Interaksi Sosial Dalam Institusi Pendidikan Era Perang dan damai di Aceh", In Paper Presented at the Aceh Development International Conference, 26-28 March 2011, Bangi, Kuala Lumpur.

Corresponding author

Suadi can be contacted at suadi@unimal.ac.id 